\title{
KEMAMPUAN PERANGKAP TIKUS DENGAN VARIASI UMPAN DALAM PENGENDALIAN TIKUS DI WILAYAH PELABUHAN PAOTERE KOTA MAKASSAR
}

Rat Trap Capabilities with Variation of Feeding in Rice Control in Paotere Port Area,

\author{
Makassar City \\ Ronny ${ }^{1}$, Ain Khaer ${ }^{2}$, Muammar ${ }^{3}$ \\ 1,2,3Poltekkes Kemenkes Makassar \\ ronnymuntu@gmail.com
}

\begin{abstract}
In the health sector, rats can become agents of several pathogens that cause disease in humans because the relationship between rats and humans is often parasitic, one of which is PES. The disease is directly caused by the saliva, urine and feces or through the bite of ectoparasites in the body of rats (fleas, fleas, and mites). This type of research aims to see the ability of the variation of bait used in order to control the rat population at Paotere Port, Makassar City. This type of research is quasi-experimental by looking at the ability of mouse traps with bait variations in rat control. The data were analyzed using one-way ANOVA statistical test using the SPSS computer program and the analyzed data were then presented in tabular form. The results of this study indicate that the four types of bait used in this study are all capable of being used as trapping bait where the total number of rats caught is 7 out of 60 traps installed. The details of the bait are as follows: papaya bait with a presentation of $13.3 \%$ from 2 rats, young cucumber bait with a presentation of $6.67 \%$ from 1 mouse, and apples with a presentation of $6.67 \%$ from 1 mouse, yellow corn bait with presentation of $20 \%$ of 3 mice. Based on the discussion, it can be concluded that the conclusion obtained from this study is that the four types of bait used are considered capable. And the most preferred germ mice are yellow corn with a percentage of $20 \%$. We recommend that employees in the Paotere Port Working Area use alternating variations of bait to make it more effective.

Keywords : Rat, Paotere Harbor, Bait Variation, Ability, Control.
\end{abstract}

\section{ABSTRAK}

Di bidang kesehatan, tikus dapat menjadi agent beberapa patogen penyebab penyakit pada manusia karena hubungan tikus dan manusia sering kali bersifat parasitisme, salah satunya penyakit PES. Penyakit tersebut secara langsung oleh ludah, urine dan fesesnya atau melalui gigitan ektoparasit yang ada di tubuh tikus (kutu, pinjal, dan tungau). Jenis Penelitian ini bertujuan untuk melihat kemampuan variasi umpan yang dipakai agar dapat mengendalikan populasi tikus di Pelabuhan Paotere Kota Makassar. Adapun jenis penelitian ini bersifat eksperimen semu dengan melihat kemampuan perangkap tikus dengan variasi umpan dalam pengendalian tikus. Data dianalisis menggunakan uji statistik ANOVA satu arah dengan menggunakan program komputer SPSS dan data yang telah dianalisis kemudian disajikan dalam bentuk tabel. Hasil penelitian ini menunjukkan bahwa keempat jenis umpan yang digunakan dalam penelitian ini semuanya mampu untuk dipakai sebagai umpan trapping di mana jumlah total tikus yang tertangkap sebanyak 7 ekor dari 60 perangkap yang terpasang. Adapun rincian umpan sebagai berikut umpan pepaya dengan presentasi $13,3 \%$ dari 2 ekor tikus, umpan mentimun muda dengan presentasi 6,67\% dari 1 ekor tikus, dan buah apel dengan presentasi $6,67 \%$ dari 1 ekor tikus, umpan jagung kuning dengan presentasi $20 \%$ dari 3 ekor tikus. Berdasarkan pembahasan maka dapat disimpulkan bahwa Kesimpulan yang didapatkan dari penelitian ini yaitu keempat jenis umpan yang digunakan dianggap mampu. Dan uman yang paling disukai tikus adalah jagung kuning dengan persentase $20 \%$. Sebaiknya pegawai pada Wilayah Kerja Pelabuhan Paotere menggunakan variasi umpan secara bergantian agar lebih efektif.

Kata kunci : Tikus, Pelabuhan Paotere, Variasi Umpan, kemampuan, Pengendalian.

\section{PENDAHULUAN}

Proyeksi Badan Perencanaan

Pembangunan Nasional (BAPPENAS) jumlah penduduk Indonesia pada 2018 mencapai 265 juta jiwa. Jumlah tersebut terdiri dari 133,17 juta jiwa laki-laki dan 131,88 juta jiwa perempuan Indonesia merupakan negara kepulauan terbesar di dunia. Menurut kelompok umur, penduduk yang masih tergolong anak-anak (0-14 tahun) mencapai 70,49 juta jiwa atau sekitar $26,6 \%$ dari total populasi. Untuk populasi yang masuk kategori usia produktif (14-64 tahun) 179,13 juta jiwa $(67,6 \%)$ dan penduduk usia lanjut $65 \mathrm{ke}$ atas sebanyak 85,89 juta jiwa $(5,8 \%)$. Dari proyeksi tersebut, jumlah kelahiran pada tahun ini mencapai 4,81 juta jiwa sedangkan jumlah kematian 1,72 juta jiwa (BAPPENAS,
2018). Dengan bertambahnya jumlah penduduk Indonesia maka akan mempengaruhi aktivitas di berbagai sektor, contohnya dalam sektor pertanian, kelautan dan perikanan, serta industri, Selain itu, diketahui banyak masyarakat Indonesia yang disibukkan berbagai pekerjaan. Aktivitas dari pekerjaan tersebut tentunya berasal dari berbagai sektor. Semakin banyak orang yang bekerja maka semakin banyak pula kebutuhan yang harus dipenuhi oleh setiap individu, mulai dari pangan, sandang, dan papan, Pemenuhan kebutuhan hidup melalui jalur transportasi laut utamanya sektor pelabuhan yang banyak memakan aktivitas muat-angkut barang merupakan contoh dari akibat aktivitas transportasi di kalangan masyarakat. Dengan adanya aktivitas muat- 
angkut barang di pelabuhan tentunya memiliki dampak negatif dan positif. Untuk dampak negatifnya menyebabkan sanitasi yang buruk pada lingkungan kawasan pelabuhan akibat pada saat proses muat-angkut barang atau penumpang tidak saniter dalam pelaksanaannya sehingga dapat memunculkan vektor penyakit atau binatang pengganggu yang akan meningkatkan angka penyakit pada masyarakat. Sedangkan untuk dampak positifnya adalah dapat mempermudah aktivitas masyarakat dalam memenuhi kebutuhan hidup masing-masing individu dan jika pada saat proses muatangkut barang atau penumpang dijaga dan diperhatikan sanitasinya maka tentunya akan menekan angka penyakit pada kehidupan masyarakat.

Paotere adalah tempat berlabuhnya perahu layar orang Sulawesi dari berbagai penjuru Indonesia. Banyak tipe perahu yang berlabuh, beberapa di antaranya, seperti perahu kecil dengan layar tunggal, serta beberapa perahu dengan layar dan mesin seperti pinisi, lambo, dan beberapa jenis lainnya. Pelabuhan ini berjarak $\pm 5 \mathrm{Km}( \pm 30$ menit) dari pusat Kota Makassar dan salah satu pelabuhan rakyat warisan tempo dulu yang masih bertahan dan merupakan bukti peninggalan Kerajaan Gowa-Tallo dan sejarah bahari dari Kota Makassar sejak abad ke-14. Pelabuhan Paotere sekarang ini masih dipakai sebagai pelabuhan perahu-perahu rakyat termasuk Pinisi, kapal khas dari Sulawesi Selatan. Hampir 24 jam aktivitas bongkar muat terjadi di Pelabuhan Paotere yang akan menuju ataupun dari kota di Indonesia bagian timur lainnya, Seperti, Balikpapan, Nunukan, Samarinda, Surabaya, Kupang, serta kota lainnya. Secara umum kondisi sanitasi lingkungan dalam kawasan Pelabuhan Paotere terkesan klasik, kotor dan marginal. Jejeran kapal pinisi yang memenuhi dermaga memberi warna klasik, khas dan menjadi daya tarik pengunjung. Sebaliknya tatanan lingkungan yang belum optimal menyebabkan lingkungan berbau busuk, got banyak yang tersumbat, sampah masih ditemukan berserakan di beberapa tempat, bangkai kapal yang tidak terurus, pemukiman, dengan kondisi tersebut sangat memungkinkan ditemukan binatang pengganggu salah satunya adalah tikus. Sesuai dengan hasil observasi yang telah dilakukan oleh peneliti, terdapat beberapa tanda keberadaan tikus yang peneliti temukan di lokasi penelitian yaitu bau dan bangkai tikus. Pada saat observasi, bau yang dicium oleh peneliti serupa dengan bau urine tikus yang sangat menyengat di sekitar pemukiman warga serta ditemukannya bangkai tubuh dari tikus yang ada di jalanan utama pelabuhan dekat pemukiman warga. Oleh karena itu, peneliti meyakini dengan adanya tanda tersebut maka memungkinkan terdapat kehidupan tikus lainnya karena seperti yang diketahui bahwa adanya seekor tikus menandakan adanya tikus lainnya yang berkembang biak di sekitar daerah tersebut.

Berdasarkan data profil Kantor Kesehatan Pelabuhan Kelas I Makassar tahun 2015 menyatakan bahwa jumlah kepadatan tikus yang tertangkap di wilayah pelabuhan Makassar sebanyak 165 ekor tikus atau rata - rata 13 ekor. Tingginya populasi tikus di pelabuhan tersebut dapat menjadi simbol bahaya yang kompleks ketika dalam tubuh tikus tersebut terdapat bakteri Leptopspira. Berdasarkan data ini menjadi penguat sebagai landasan pada latar belakang, penulis memperoleh hasil penelitian yang dilakukan oleh (Mulyono and Ristiyanto, 2009), Kota Salatiga menunjukkan bahwa tikus Rattus Norvegicus yang infektif Leptospira Sp sebanyak 8 ekor dari 11 ekor. Penelitian serupa dilakukan oleh (Yunianto et al., 2012)di Kota Semarang menunjukkan proporsi terbesar dari spesies tikus yang yang positif mengandung Leptospira adalah Rattus Norvegicus. Berdasarkan (Joharina et al., 2016), terdapat beberapa penyakit akibat tikus yang dapat ditularkan ke manusia dan cara penularannya adalah Leptospirosis berasal dari bakteri Spirochete/Leptospira Sp. Ditularkan melalui selaput lendir atau luka dikulit bila terpapar oleh air yang tercemar darah dan urine tikus, Pes/Plague-Bakteri Yersinia pestis melalui gigitan pinjal tikus, keracunan makanan/food poisoning Salmonellisis melalui kontaminasi kotoran tikus di permukaan makanan yang menimbulkan pencemaran makanan, Demam gigitan tikus Rat Feveryaitu berasal dari bakteri Spirillum $\mathrm{Sp}$ atau Streptobacillus Sp yaitu melalui gigitan tikus karena bakteri tersebut bersembunyi di mulut dan hidung tikus.

Dengan adanya tanda-tanda keberadaan tikus dikaitkan dengan kebiasaan makan serta Indera tikus yang biasanya dipakai dan membuat tikus peka sehingga diharapkan mampu masuk ke trapping maka penulis ingin memberikan variasi umpan sebagai tolak ukur mampu atau tidaknya umpan yang digunakan ketika memancing tikus masuk ke dalam perangkap. Adapun 
umpan yang akan digunakan pada penelitian ini adalah empat jenis umpan yaitu buah pepaya matang, mentimun muda, buah apel, dan jagung kuning. Berdasarkan Penelitian (Asmariani and Probosari, 2012), menyatakan bahwa kandungan buah pepaya memiliki kandungan zat warna betaqaroten yang menyebabkan buah pepaya berwarna jingga. Hal inilah yang dapat memancing kepekaan Indera penglihatan dari tikus. Menurut jurnal hasil penelitian (Hakim and Saputri, 2017), menyatakan bahwa di dalam buah mentimun terdapat senyawa alkaloid, saponin, tanin dan senyawa fenol yang menyebabkan timbulnya bau khas dari buah tersebut untuk memancing Indera penciuman dari tikus. Sedangkan jurnal hasil penelitian dari (Pardede, 2013), bahwa zat-zat karotin pada buah apel merupakan penyebab adanya pigmen warna dalam buah apel spesifik pada kulitnya. Dengan demikian, dengan adanya pigmen warna karotis tersebut maka dapat memancing Indera penglihatan tikus. Terakhir, kandungan dari jagung kuning melalui hasil penelitian dari (Koswara, 2009), yang juga tercantum pada makalah seminarnya menyatakan bahwa senyawa karotenoid dapat berupa karotin $(\mathrm{C} 4 \mathrm{OH} 56)$ berwarna jingga dan xantofil (C4OH56O2) berwarna kuning. Hal inilah yang dapat menyebabkan pigmen kuning pada jagung sehingga diharapkan mampu menjadikan Indera penglihatan tikus menjadi lebih peka.

\section{BAHAN DAN METODE Jenis Penelitian}

Jenis penelitian ini merupakan penelitian Eksperimen semu (QuasiExperimental) yaitu kemampuan perangkap tikus dengan variasi umpan dalam pengendalian tikus di Pelabuhan Paotere Kota Makassar.

\section{Lokasi Penelitian}

1. Lokasi pengujian variasi umpan yaitu di laksanakan di Pelabuhan Paotere Kota Makassar.

2. Lokasi Pemeriksaan/identifikasi yaitu Laboratorium Vektor Kantor Kesehatan Pelabuhan Kelas 1 Makassar wilayah kerja Pelabuhan Soekarno Hatta.

\section{Waktu Penelitian}

Waktu penelitian terbagi 2 tahap :

1. Tahap Persiapan : Bulan Desember 2018 - Januari 2019

2. Tahap Penelitian : Bulan Maret 2019 Mei 2019

\section{Desain dan Variabel Penelitian}

1. Desain Penelitian

Berdasarkan tujuan penelitian, yaitu kemampuan perangkap tikus dengan variasi umpan dalam pengendalian tikus di wilayah Pelabuhan Paotere Kota Makassar.
2. Variabel Penelitian
a. Variabel Bebas
b. Variabel Terikat
c. Variabel Pengganggu

\section{Populasi dan Sampel}

\section{Populasi}

Populasi dalam penelitian ini adalah semua jenis tikus yang ada di Pelabuhan Paotere Kota Makassar.

\section{Sampel}

Sampel dalam penelitian ini adalah semua tikus yang tertangkap pada trapping yaitu dua sampel dengan umpan buah papaya matang, mentimun muda, buah apel, dan jagung kuning.

\section{Pengumpulan Data}

1. Data Primer

Data primer adalah Data yang diperoleh setelah dilakukan observasi lokasi dan sesudah pemasangan perangkap serta identifikasi tikus di Laboratorium Vektor kantor kesehatan pelabuhan kelas 1 Makassar wilayah kerja pelabuhan Soekarno Hatta.

\section{Data Sekunder}

Data sekunder adalah data yang diperoleh dari berbagai referensi baik artikel - artikel, jurnal, buku maupun literatur yang ada dengan penelitian ini.

\section{HASIL DAN PEMBAHASAN}

Proses pemasangan perangkap dengan variasi umpan dilakukan tanggal 2830 April 2019 di Pelabuhan Paotere khususnya di wilayah parimetri dalam hal ini di dalam rumah warga, halaman rumah warga serta di bagian lelong. Umpan yang dipakai terdapat 4 jenis variasi yaitu buah pepaya, mentimun muda, jagung kuning, dan buah apel. Dalam tiga hari tersebut dilakukan replikasi dari memulai hingga mengakhiri pemasangan keempat jenis umpan. Pemasangan umpan dilakukan pada sore hari pukul 17.30-18.30 WITA dan pengambilan perangkap pada pagi hari pukul 06.00-07.00 WITA. Dalam sehari, total keseluruhan perangkap yang terpasang sebanyak 20 perangkap dengan replikasi selama tiga hari, 
artinya ada 60 perangkap yang terpasang dengan menggunakan keempat jenis umpan yaitu, pepaya matang, mentimun muda, buah apel, jagung kuning. Proses identifikasi tikus di lakukan di Laboratorium Vektor Kantor Kesehatan Pelabuhan Soekarno Hatta Kelas I Makassar selama 3 hari (29 Mei-01 April 2019) yang dibuktikan dengan hasil spesifikasi jenis tikus dan umpan termakan.

Adapun hasil yang didapatkan selama penelitian ini berlangsung dengan acuan success trap yang terdapat pada acuan Peraturan Kementerian Kesehatan No. 50 Tahun 2017 tentang Standar Baku Mutu Kesehatan Lingkungan dan Persyaratan Kesehatan Untuk Vektor dan Binatang Pembawa Penyakit Serta Pengendaliannya, dan jumlah tikus yang tertangkap pada umpan papaya sebanyak dua ekor dengan persentase success trap sebesar 13,3\% (keberhasilan penangkapan) dengan acuan bahwa perangkap mapu mampu menangkap tikus lebih dari satu ekor. sehingga umpan pepaya matang dikatakan mampu digunakan sebagai umpan dalam pemasangan trapping, untuk umpan mentimun muda jumlah tikus yang tertangkap berjumlah satu ekor dengan persentase success trap sebesar 6,67\% sehingga umpan mentimun muda dikatakan mampu digunakan sebagai umpan dalam pemasangan trapping, dan jumlah tikus yang tertangkap pada umpan buah apel berjumlah satu ekor dengan persentasi success trap sebesar $6,67 \% \%$ sehingga umpan buah apel dikatakan mampu digunakan sebagai umpan dalam pemasangan trapping, dan untuk umpan jagung kuning jumlah tikus yang tertangkap sebanyak tiga ekor dengan persentasi success trap sebesar $20 \%$ sehingga umpan jagung kuning dikatakan mampu digunakan sebagai umpan dalam pemasangan trapping, Adapun umpan yang telah diuji di lapangan diurutkan berdasarkan persentase umpan yang paling besar sebagai berikut.

Tabel 1

Urutan Keberhasilan Umpan

\begin{tabular}{|c|c|c|}
\hline \\
\hline $\begin{array}{l}\text { Jenis } \\
\text { Umpan }\end{array}$ & $\begin{array}{l}\text { Persentasi / } \\
\text { Jumlah Tikus }\end{array}$ & $\begin{array}{c}\text { Lokasi } \\
\text { Pemasangan }\end{array}$ \\
\hline $\begin{array}{l}\text { Jagung } \\
\text { Kuning }\end{array}$ & $\begin{array}{l}20 \% \\
\text { / } 3 \text { Ekor }\end{array}$ & $\begin{array}{l}\text { Kawasan } \\
\text { pelabuhan }\end{array}$ \\
\hline $\begin{array}{l}\text { Pepaya } \\
\text { Matang }\end{array}$ & $\begin{array}{l}13,3 \% \\
\text { / } 2 \text { Ekor }\end{array}$ & $\begin{array}{l}\text { Rumah } \\
\text { warga }\end{array}$ \\
\hline $\begin{array}{l}\text { Mentimun } \\
\text { Muda }\end{array}$ & $\begin{array}{l}\text { 6,67\% } \\
\text { /1 Ekor }\end{array}$ & $\begin{array}{l}\text { Rumah } \\
\text { warga }\end{array}$ \\
\hline $\begin{array}{l}\text { Buah } \\
\text { Apel }\end{array}$ & $\begin{array}{l}\text { 6,67\% } \\
\text { / 1 Ekor }\end{array}$ & $\begin{array}{c}\text { Halaman rumah } \\
\text { warga }\end{array}$ \\
\hline
\end{tabular}

Sumber : Data Primer tahun 2019

Tabel 2
Cuplikan Hasil Uji Laboratorium KKP Kelas I Makassar Wilayah Kerja Pelabuhan Soekarno Hatta

\begin{tabular}{|c|c|c|c|c|}
\hline $\begin{array}{c}\text { Pemeriksa } \\
\text { an }\end{array}$ & $\begin{array}{c}\text { Lokasi } \\
\text { Pemasang } \\
\text { an }\end{array}$ & Umpan & $\begin{array}{c}\text { Jenis } \\
\text { Kelami } \\
n\end{array}$ & $\begin{array}{l}\text { Jenis } \\
\text { Tikus }\end{array}$ \\
\hline \multirow[t]{5}{*}{$\begin{array}{c}\text { HARI } \\
\text { PERTAMA }\end{array}$} & \multirow{5}{*}{$\begin{array}{l}\text { Kawasan } \\
\text { Pelabuhan } \\
\text { Paotere }\end{array}$} & $\begin{array}{l}\text { Pepaya } \\
\text { Matang }\end{array}$ & - & - \\
\hline & & $\begin{array}{l}\text { Mentimu } \\
\text { n Muda }\end{array}$ & - & - \\
\hline & & Apel & 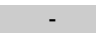 & - \\
\hline & & $\begin{array}{l}\text { Jagung } \\
\text { Kuning }\end{array}$ & $\begin{array}{l}2 \text { Ekor } \\
\text { Betina }\end{array}$ & $\begin{array}{c}\text { Rattus } \\
\text { Norvegic } \\
\text { us Dan } \\
\text { Rattus } \\
\text { Tanezum } \\
\text { i/Rattus } \\
\text { Rattus }\end{array}$ \\
\hline & & & $\begin{array}{l}1 \text { Ekor } \\
\text { Jantan }\end{array}$ & $\begin{array}{l}\text { Rattus } \\
\text { Norvegic } \\
\text { us }\end{array}$ \\
\hline \multirow{5}{*}{$\begin{array}{c}\text { HARI } \\
\text { KEDUA }\end{array}$} & \multirow{5}{*}{$\begin{array}{l}\text { Rumah } \\
\text { Warga }\end{array}$} & Pepaya & 1 Ekor & Rattus \\
\hline & & Matang & Betina & $\begin{array}{c}\text { Tanezum } \\
\text { i/Rattus } \\
\text { Rattus }\end{array}$ \\
\hline & & $\begin{array}{l}\text { Mentimu } \\
\text { n Muda }\end{array}$ & $\begin{array}{l}1 \text { Ekor } \\
\text { Jantan }\end{array}$ & $\begin{array}{l}\text { Rattus } \\
\text { Norvegic } \\
\text { us }\end{array}$ \\
\hline & & Apel & - & - \\
\hline & & $\begin{array}{l}\text { Jagung } \\
\text { Kuning }\end{array}$ & - & - \\
\hline \multirow[t]{4}{*}{$\begin{array}{c}\text { HARI } \\
\text { KETIGA }\end{array}$} & \multirow{4}{*}{$\begin{array}{c}\text { Rumah } \\
\text { Warga Dan } \\
\text { Halaman } \\
\text { Rumah } \\
\text { Warga }\end{array}$} & $\begin{array}{l}\text { Pepaya } \\
\text { Matang }\end{array}$ & $\begin{array}{l}1 \text { Ekor } \\
\text { Betina }\end{array}$ & $\begin{array}{c}\text { Rattus } \\
\text { Norvegic } \\
\text { us }\end{array}$ \\
\hline & & $\begin{array}{c}\text { Mentimu } \\
\text { n Muda }\end{array}$ & - & - \\
\hline & & Apel & $\begin{array}{l}1 \text { Ekor } \\
\text { Betina }\end{array}$ & $\begin{array}{l}\text { Rattus } \\
\text { Norvegic } \\
\text { us }\end{array}$ \\
\hline & & $\begin{array}{l}\text { Jagung } \\
\text { Kuning }\end{array}$ & - & - \\
\hline
\end{tabular}

\section{Kemampuan umpan pepaya dalam pengendalian tikus}

Berdasarkan hasil penelitian yang telah dilakukan dimana umpan dipasang di kawasan parimetri Pelabuhan Paotere. Jumlah tikus yang tertangkap pada umpan papaya berjumlah dua ekor, dan keduanya berbeda jenis. Dalam jumlah perangkap yang terpasang sebanyak 15 buah, 2 diantaranya berhasil dimakan oleh tikus sehingga terperangkap dan didapatkan dua jenis yaitu Rattus norvegicus dan Rattus tanezumi atau rattus rattus. Adapun 13 perangkap lainnya terdapat perbedaan hasil di lapangan dengan rincian 8 perangkap yang terbuka dengan keadaan umpan masih tersedia dan 5 perangkap dengan kondisi tertutup dengan kondisi umpan yang tidak tersedia. Berdasarkan Penelitian (Asmariani and Probosari, 2012) menyatakan bahwa kandungan buah pepaya memiliki zat warna betaqaroten yang menyebabkan buah pepaya berwarna jingga. Hal inilah yang dapat memancing kepekaan Indera penglihatan dari tikus. Pepaya memiliki warna yang sangat mencolok yaitu warna kuning hingga jingga 
sehingga dapat menarik simpati dari tikus untuk bergerak ke perangkap yang dipasangi umpan pepaya. Pada saat melakukan penelitian terhitung tanggal 28-30 April 2019, didapatkan hasil bahwa ada 2 jenis tikus yang terperangkap dengan persentase sebesar $13,3 \%$ dan memakan umpan pepaya di kawasan rumah warga dengan masingmasing jenis yaitu Rattus tanezumi dan Rattus norvegicus setelah diidentifikasi pada tanggal 30 April dan 01 Mei 2019. Dengan demikian, umpan pepaya mampu digunakan untuk mengendalikan tikus yang ada di Pelabuhan Paotere Kota Makassar menurut Peraturan Kementerian Kesehatan No. 50 Tahun 2017 tentang Standar Baku Mutu Kesehatan Lingkungan dan Persyaratan Kesehatan Untuk Vektor dan Binatang Pembawa Penyakit Serta Pengendaliannya yaitu umpan dikatakan mampu mengendalikan jika terdapat $\geq 1$ ekor tikus terperangkap.

\section{Kemampuan umpan mentimun muda dalam pengendalian tikus}

Berdasarkan hasil penelitian yang

telah dilakukan di kawasan parimetri Pelabuhan Paotere, jumlah tikus yang tertangkap pada umpan mentimun muda berjumlah satu ekor. Jumlah perangkap yang terpasang sebanyak 15 buah, satu di antaranya berhasil dimakan oleh tikus sehingga terperangkap dan didapatkan jenis Rattus norvegicus. Adapun 14 perangkap lainnya terdapat perbedaan hasil di lapangan dengan rincian 10 perangkap yang terbuka dengan keadaan umpan masih tersedia dan 4 perangkap dengan kondisi tertutup dengan kondisi umpan yang tidak tersedia. Menurut jurnal hasil penelitian sebelumnya tentang Prevalensi Pengendalian Tikus Metode Variasi Umpan melalui Identifikasi Senyawa Kimia Ekstrak Etanol Cucumis L. oleh (Hakim and Saputri, 2017), menyatakan bahwa di dalam buah mentimun terdapat senyawa alkaloid, saponin, tanin dan senyawa fenol yang menyebabkan timbulnya bau khas dari buah tersebut untuk memancing indera penciuman dari tikus. Selain itu, terdapat senyawa terpenoid yaitu senyawa khas yang dimiliki oleh mentimun sehingga cukup jelas baunya. Hal inilah yang menjadikan indera penciuman tikus cukup peka sehingga masuk ke dalam jebakan perangkap yang di pasang. Hasil yang didapatkan hanya 1 ekor tikus terperangkap dengan persentase sebesar $6,67 \%$ dengan jenis Rattus norvegicus (Selengkapnya lihat pada lampiran 6) terhitung tanggal 30 April 2019 pada rumah warga sebagai lokasi pemasangan. Dengan demikian, umpan mentimun mampu digunakan untuk mengendalikan tikus yang ada di Pelabuhan Paotere Kota Makassar, hal ini tercantum dalam Peraturan Kementerian Kesehatan No. 50 Tahun 2017 tentang Standar Baku Mutu Kesehatan Lingkungan dan Persyaratan Kesehatan Untuk Vektor dan Binatang Pembawa Penyakit Serta Pengendaliannya yaitu umpan dikatakan mampu mengendalikan jika terdapat $\geq 1$ ekor tikus terperangkap.

\section{Pembahasan tentang umpan buah apel dalam pengendalian tikus}

Berdasarkan hasil penelitian yang telah dilakukan di kawasan Parimetri Pelabuhan Paotere, jumlah tikus yang tertangkap pada umpan buah apel berjumlah satu ekor, dengan jenis Rattus norvergicus dan jumlah perangkap yang terpasang sebanyak 15 buah. Satu di antaranya berhasil dimakan oleh tikus sehingga terperangkap dan didapatkan jenis Rattus norvegicus. Adapun 14 perangkap lainnya terdapat perbedaan hasil di lapangan dengan rincian 12 perangkap yang terbuka dengan keadaan umpan masih tersedia dan 2 perangkap dengan kondisi tertutup dengan kondisi umpan yang tidak tersedia. Jurnal hasil penelitian dari (Pardede, 2013), bahwa zat-zat karotein pada buah apel merupakan penyebab adanya pigmen warna dalam buah apel spesifik pada kulitnya. Selain itu, memiliki senyawa saporenin yang mengeluarkan bau khas dari buah apel. Dengan demikian, adanya pigmen warna karoteid tersebut maka dapat memancing Indera penglihatan dan penciuman tikus. Adapun hasil yang didapatkan terhitung tanggal 01 Mei 2019 hanya 1 ekor tikus terperangkap dengan persentase sebesar $6,67 \%$ dengan jenis Rattus norvegicus di halaman rumah warga sebagai lokasi pemasangan. Dengan demikian, umpan apel mampu digunakan untuk mengendalikan tikus yang ada di Pelabuhan Paotere Kota Makassar, tercantum dalam Peraturan Kementerian Kesehatan No. 50 Tahun 2017 tentang Standar Baku Mutu Kesehatan Lingkungan dan Persyaratan Kesehatan Untuk Vektor dan Binatang Pembawa Penyakit Serta Pengendaliannya yaitu umpan dikatakan mampu mengendalikan jika terdapat $\geq 1$ ekor tikus terperangkap. 


\section{Pembahasan tentang umpan jagung kuning dalam pengendalian tikus}

Berdasarkan hasil penelitian yang telah dilakukan di kawasan Parimetri Pelabuhan Paotere, jumlah tikus yang tertangkap pada umpan jagung kuning berjumlah 3 ekor yang berbeda jenis. Dalam jumlah perangkap yang terpasang sebanyak 15 buah, 3 di antaranya berhasil dimakan oleh tikus sehingga terperangkap dan didapatkan dua jenis yaitu 2 ekor Rattus norvegicus dan seekor Rattus tanezumi atau rattus rattus.

Adapun 13 perangkap lainnya terdapat perbedaan hasil di lapangan dengan rincian 5 perangkap yang terbuka dengan keadaan umpan masih tersedia dan 8 perangkap dengan kondisi tertutup dengan kondisi umpan yang tidak tersedia. Kandungan dari jagung kuning melalui hasil penelitian dari (Koswara, 2009), yang juga tercantum pada makalah seminarnya menyatakan bahwa senyawa karotenoid dapat berupa karotin (C4OH56) berwarna jingga dan xantofil (C4OH56O2) berwarna kuning. Hal inilah yang dapat menyebabkan pigmen kuning pada jagung sehingga diharapkan mampu menjadikan Indera penglihatan tikus menjadi lebih peka selain itu berdasarkan dengan teori kesukaan yang pernah peneliti baca bahwa tikus menyukai makanan seperti biji-bijian seperti halnya jagung. Inilah penyebab banyaknya jagung kuning yang berhasil menjadi umpan tikus dibandingkan dengan umpan yang lain dengan persentase sebesar $20 \%$. Ketika di lapangan, hasil yang didapatkan adalah 2 jenis tikus dengan yaitu 2 ekor Rattus norvegicus dan 1 ekor Rattus tanezumi. Hal yang menarik dalam pengidentifikasian di Laboratorium Vektor KKP Kelas I Makassar, ternyata ada 1 ekor Rattus norvegicus yang memiliki berat tubuh sangat fantastis yaitu 560 gram (Setengah kilogram lebih) dengan jenis kelamin jantan. Adapun yang memungkinkan beratnya seperti itu adalah kondisi lingkungan hidup yang ada di daerah tersebut seperti ikan maupun sisa-sisa makanan (sampah) yang dibuang di TPS Pelabuhan Paotere sehingga dapat menunjang kualitas hidup dari tikus got tersebut. Hal lain yang menjadi faktor pengaruh adalah besar dan dalamnya got dengan keadaan lembap yang menjadikan tikus ini betah untuk hidup dan berlalu-lalang di kawasan ini. Dengan demikian, umpan jagung kuning mampu digunakan untuk mengendalikan tikus yang ada di Pelabuhan Paotere Kota Makassar, hal tersebut diperjelas dalam Peraturan Kementerian Kesehatan No. 50 Tahun 2017 tentang Standar Baku Mutu Kesehatan Lingkungan dan Persyaratan Kesehatan Untuk Vektor dan Binatang Pembawa Penyakit Serta Pengendaliannya yaitu umpan dikatakan mampu mengendalikan jika terdapat $\geq 1$ ekor tikus terperangkap.

Rattus norvegicus lebih banyak ditemukan di lokasi tersebut karena beberapa faktor yaitu pada alur rantai makanan, untuk mempertahankan hidupnya ular atau sejenisnya memakan tikus. Namun, menurut laporan warga dan survei di lokasi tidak ditemukan adanya ular atau tidak adanya hewan lain yang memangsa tikus (utamanya got) sehingga dapat menjadi celah Rattus norvegicus hidup dan berkembang-biak di kawasan perimeter Pelabuhan Paotere utamanya di got-got sekitar rumah warga dan kawasan pelabuhan. Selain itu, Rattus norvegicus terkenal dengan bionomik hidupnya yaitu di got atau lorong/gang sempit/riol, gelap, kotor, dan agak lembab sesuai dengan kondisi di lapangan sehingga memengaruhi kuantitas dari Rattus norvegicus. Di lain sisi, menurut jurnal penelitian (Dewi, 2010), menjelaskan bahwa mamalia ini mempunyai kadar metabolisme yang tinggi, aktif, serta pergerakan yang tinggi. Kebaikan menjadi mamalia kecil ialah kemudahan untuk melindungi dan menyembunyikan diri dari pemangsa. Faktor terakhir adalah karena tikus ini lebih cepat dewasa, tidak memperlihatkan perkawinan musiman dan lebih mudah berkembang biak. Breeding interval $R$. norvegicus dapat berkembang biak hingga 7 kali per tahun (Dewi, 2010).

Keberadaan Rattus norvegicus dan Rattus tanezumi dipicu oleh banyak faktor. Untuk Rattus norvegicus, banyak dijumpai di saluran air/riul/got di daerah pemukiman kota, pelabuhan, dan pasar (utamanya di dalam rumah warga, halaman rumah warga, kawasan Pelabuhan Paotere, dan belakang rumah warga). Adanya riul/got di dalam rumah warga menjadi sasaran empuk tikus ini untuk mencari sumber makanan. Rattus norvegicus telah menyebabkan lebih banyak kematian jika dibandingkan dengan semua perang dalam sejarah. Rat-borne diseases diperkirakan telah menewaskan banyak orang dalam 1000 tahun terakhir. Mereka merupakan ancaman bagi kesehatan masyarakat. Mereka menjadi hospes dari kutu dan pinjal yang dapat menyebabkan pes, trichinosus, tularemia, infeksi penyakit kuning, 
demam tifus endemik, ratbite fever, dan beberapa penyakit berbahaya (Myers and Armitage, 2004). Tikus ini termasuk hewan nokturnal tetapi kadangkala dijumpai juga pada siang hari mencari makanan. Kebiasaan makannya menggunakan Indera penciuman dan sentuhan. Mereka mampu bertahan cukup mudah jika terdapat pasokan dari sisa makanan manusia. Keberadaan tikus di lingkungan rumah tangga adalah salah satu bukti eratnya hubungan tikus dengan manusia. Rattus norvegicus merupakan jenis tikus yang menggunakan rumah, got, riul, dan sekitarnya sebagai habitat. Makin dekat hubungannya dengan manusia, tikus semakin dirasakan gangguannya. Sebagai binatang nokturnal, suara yang ditimbulkan dapat menimbulkan kegaduhan malam hari. Interaksi tikus dengan manusia secara langsung sangat membahayakan. Hal ini dikarenakan vektor penyakit manusia yang berinteraksi dengan tikus (parasitisme) adalah berbagai jenis ektoparasit.

Sedangkan Rattus tanezumi sebagian besar didapatkan di dalam los rumah. Hal ini karena Rattus tanezumi termasuk tikus jenis domestik. Tikus domestik beraktivitas terutama mencari makan, bertahan hidup, berkembang biak, dan bersarang di dalam rumah.

Dalam jurnal Agustini menunjukkan spesies tikus terbanyak yang ditemukan di dalam rumah $(62,22 \%)$ adalah Rattus tanezumi. Keberagaman pangan di dalam rumah seperti beras, telur, Mi Instan, daging, roti, dan susu merupakan sembako yang bisa menjadi sumber makanan tikus jenis Rattus tanezumi. Selain itu, semakin banyak los yang ada di dalam rumah maka semakin banyak pula kemungkinan Rattus tanezumi dapat hidup, berkembang biak, dan bersarang. Hal ini diperkuat dalam (Ernawati and Priyanto, 2013), yang mengatakan bahwa banyaknya los dalam rumah sebenarnya menjadi sarang baru untuk tikus jenis Rattus tanezumi untuk mempertahankan hidupnya dengan memakan apa yang ada di los-los rumah warga.

Keberhasilan variasi umpan dalam perangkap menuai banyak hambatan yang bisa dilalui oleh peneliti. Mulai dari tikus yang sudah masuk ke dalam perangkap namun berhasil mendorong pintu perangkap sehingga lolos dari trapping atau umpan yang sama sekali tidak disentuh oleh vektor ini. Namun, banyak faktor yang menyebabkan hal demikian dapat terjadi, beberapa di antaranya adalah kebiasaan makan dengan makanan sesuai dengan apa yang dimakan oleh warga sekitar sehingga tikus tidak ingin memakan umpan, terdapat bau tangan manusia (dalam hal ini warga sekitar) yang mengganggu/ memindahkan perangkap, adanya hewan pengganggu seperti ayam, kucing, dan anjing.

Menurut (Bari et al., 2020), dalam penelitiannya tentang hubungan gangguan predator terhadap tikus bahwa tikus yang diberi perlakuan suara predator mengalami gangguan pola aktivitas harian yang ditandai dengan jumlah waktu yang dihabiskan untuk locomotion (bergerak), foraging (makan dan minum) dan resting (terdiam dan tidur) sehingga dapat menyebabkan tikus stress. Selain itu, terdapat aktivitas manusia yang berlalu-lalang pada kawasan pelabuhan yang menyebabkan tikus enggan mendekati perangkap. Faktor lain juga dijelaskan langsung oleh petugas identifikasi vektor di Laboratorium mengatakan bahwa sebenarnya sidik jari manusia pada umpan atau perangkap menjadi faktor utama mengapa tikus tidak tertarik memakan umpan atau karena orang yang mengerjakan umpan tidak saniter, terakhir yaitu perangkap tidak bersih dicuci lalu digunakan lagi. Meskipun seperti itu, peneliti mengupayakan dalam melakukan pemasangan baik umpan dan perangkap secara saniter dari segala prosedurnya dengan konsisten menggunakan masker dan sarung tangan ketika melakukan proses penelitian hingga proses akhir penelitian (Pencucian perangkap). Hal ini dilakukan sebagai bentuk keseriusan peneliti untuk menguji kemampuan empat umpan yang dipakai dalam penelitian ini sehingga meminimalisir sebaik mungkin faktor yang berpengaruh pada percobaan kali ini. Adapun pada saat pengerjaan umpan, dicuci kemudian dipotong-potong lalu dimasukkan ke dalam freezer (Untuk mempertahankan teksturnya) ternyata tidak baik dilakukan karena masa tahannya ketika di suhu ruang tidak lama (mudah membusuk) sehingga peneliti mengulangi pengerjaan umpan dengan cara mengerjakan umpan ketika hendak dipakai saja lalu dipasang pada perangkap yang bersih agar umpan tersebut tahan dan tidak cepat membusuk sehingga tikus lebih mudah tertarik pada umpan.

Hubungan tikus dan manusia sering kali bersifat parasitisme. Di bidang kesehatan tikus dapat menjadi agent beberapa patogen penyebab penyakit pada manusia, baik hewan, ternak maupun peliharaan. Jenis penyakit yang dibawa oleh tikus antara lain pes, leptospirosis, murine typus, scrubtypus, 
leishmeniasis, salmonelosis, penyakit chagas dan juga beberapa penyakit cacing seperti schistosomiasis dan angiostrongyliasis. Penyakit tersebut dapat ditularkan kepada manusia secara langsung oleh ludah, urin dan fesesnya atau melalui gigitan ektoparasit yang ada di tubuh tikus (kutu, pinjal, caplak dan tungau). Dibandingkan ektoparasit lainnya, ektoparasit pinjal mempunyai peran penting dalam bidang kesehatan karena berperan sebagai vektor penyakit di antaranya adalah penyakit pes (Priyotomo et al., 2015).

Adapun teori yang menunjang penelitian ini sejalan dengan teori Haard pada tahun 1985 dalam buku Characteristics of Edible Plants Tissue yang menyatakan bahwa apel termasuk jenis bahan pakan buah yang banyak mengandung komponen karbohidrat sederhana yang mudah dicerna dan mudah larut seperti glukosa. Ketersediaan komponen tersebut pada buah-buahan sangat memungkinkan dimanfaatkan secara langsung sebagai sumber energi oleh tikus. Oleh karena itu, buah-buahan lebih disukai dan dipilih daripada tumbuhan hijau (dedaunan) sebagai makanan yang lebih banyak mengandung seratsa, fruktosa dan sukrosa (Haard, 1976). Dengan teori tersebut peneliti mengambil dua jurnal penelitian sebagai pembanding, adapun jurnal yang didapatkan yaitu berdasarkan penelitian yang dilakukan oleh (Nugroho, 2015), umpan yang paling banyak dimakan tikus adalah buah mentimun muda dan jumlah tikus yang tertangkap sebanyak 9 ekor, penelitian yang serupa dilakukan oleh Elfira Septiani Hamid pada tahun 2014 umpan yang paling banyak dimakan oleh tikus adalah jagung dan tikus yang tertangkap sebanyak 6 ekor sedangkan dari hasil penelitian saya bahwa yang paling banyak disukai tikus adalah jagung kuning dan jumlah tikus yang tertangkap sebanyak 3 ekor (Hamid, 2015)..

\section{KESIMPULAN}

Dari hasil penelitian dan analisis yang telah diuraikan, kesimpulan yang diperoleh sebagai berikut:

1. Umpan buah pepaya mampu dalam pengendalian tikus dengan persentase $13,3 \%$.

2. Umpan mentimun muda mampu dalam pengendalian tikus dengan persentase $6,67 \%$

3. Umpan buah apel mampu dalam pengendalian tikus dengan persentase $6,67 \%$.

4. Umpan jagung kuning mampu dalam pengendalian tikus dengan persentase $20 \%$.

\section{SARAN}

1. Bagi masyarakat, sebaiknya masyarakat dapat memilih umpan jagung kuning mengingat berdasarkan penelitian ini jagung kuning memiliki presentasi tertinggi dalam pengendalian tikus dengan metode trapping.

2. Bagi pegawai Kantor kesehatan Pelabuhan kelas 1 Makassar wilayah kerja Pelabuhan Paotere, sebaiknya menggunakan keempat umpan secara bergantian agar lebih bervariasi dan efektif dalam pengendalian tikus.

3. Bagi institusi, sebaiknya skripsi ini dapat digunakan dalam proses pembelajaran serta sebagai sumber referensi.

\section{DAFTAR PUSTAKA}

Asmariani, W. G. and Probosari, E. (2012) 'Pengaruh pemberian buah pepaya (Carica papaya L.) terhadap kadar kolesterol LDL dan kolesterol HDL pada tikus Sprague Dawley dengan hiperkolesterolemia'. Diponegoro University.

BAPPENAS (2018) 'Indonesian Biodiversity Strategy and Action Plan (IBSAP) 2015-2020'.

Bari, I. N. et al. (2020) 'Effect of Plumeria rubra (Apocynaceae) leaf extracts, a repellent of ricefield rats (Rattus argentiventer), on its metabolism and daily activity', Revista de Biología Tropical, 68(4).

Dewi, D. I. (2010) 'Tikus riul (Rattus norvegicus Berkenhout, 1769)', BALABA: JURNAL LITBANG PENGENDALIAN PENYAKIT BERSUMBER BINATANG BANJARNEGARA, pp. 22-23.

Ernawati, D. and Priyanto, D. (2013) 'Pola Sebaran Spesies Tikus Habitat Pasar berdasarkan jenis komoditas di pasar Kota Banjarnegara', BALABA: JURNAL LITBANG 
Jurnal Sulolipu : Media Komunikasi Sivitas Akademika dan Masyarakat

Vol. 20 No.2 2020

e-issn : 2622-6960, p-issn : 0854-624X

PENGENDALIAN PENYAKIT BERSUMBER BINATANG BANJARNEGARA, pp. 58-62.

Haard, N. F. (1976) 'Characteristics of edible plant tissues', Principles of food science.

Hakim, A. R. and Saputri, R. (2017) 'Identifikasi Senyawa Kimia Ekstrak Etanol Mentimun (Cucumis sativus L.) dan Ekstrak Etanol Nanas (Ananas comosus (L) Merr.)', Jurnal Pharmascience, 4(1).

Hamid, E. S. (2015) 'uji perbedaan jenis umpan perangkap tikus dikota gorontalo tahun 2014', Skripsi, 1(811410005).

Joharina, A. S. et al. (2016) 'Rickettsia pada pinjal tikus (Xenopsylla cheopis) di daerah Pelabuhan Semarang, Kupang dan Maumere', Indonesian Bulletin of Health Research. National Institute of Health Research and Development, Indonesian Ministry ..., 44(4), pp. 237-244.

Koswara, S. (2009) 'Teknologi pengolahan jagung (teori dan praktek)', Jakarta: Penerbit Dian Rakyat.

Mulyono, A. and Ristiyanto, R. (2009) 'Karakteristik Histopatologi Hepar Tikus Got Rattus Norvegicus Infektif Leptospira SP.', Vektora: Jurnal Vektor dan Reservoir Penyakit. National Institute of Health Research and Development, Indonesian Ministry ..., 1(2), pp. 84-92.

Myers, P. and Armitage, D. (2004) 'Rattus norvegicus', On-line), Animal Diversity Web. Accessed March, 27, p. 2006.

Nugroho, A. M. (2015) 'Pengaruh Gel Ekstrak dan Serbuk Mentimun (Cucumis sativus) terhadap Angiogenesis pada Penyembuhan Luka Bakar Derajat IIB pada Tikus Wistar'.

Pardede, E. (2013) 'Tinjauan komposisi kimia buah dan sayur: Peranan sebagai nutrisi dan kaitannya dengan teknologi pengawetan dan pengolahan', J. VISI, 21(3), pp. 1-16.

Priyotomo, Y. C. et al. (2015) 'Studi Kepadatan Tikus dan Ektoparasit di Daerah Perimeter dan Bufferpelabuhan Laut Cilacap', Jurnal Kesehatan Masyarakat (e-Journal). Fakultas Kesehatan Masyarakat, 3(2), pp. 86-95.

Yunianto, B. et al. (2012) 'Studi reservoir dan distribusi kasus leptospirosis di Kabupaten Gresik Tahun 2010', Indonesian Journal of Health Ecology. National Institute of Health Research and Development, Indonesian Ministry ..., 11(1), p. 79772. 